\title{
AGROTEKNIKA
}

ISSN: 2685-3450 (Online)

www.agroteknika.id

ISSN: 2685-3450 (Print)

\section{Analisis Kelayakan Finansial Agroindustri Kerupuk Kulit Menggunakan Mesin Peniris di Kecamatan Selong, Kabupaten Lombok Timur}

\section{Financial Feasibility Analysis of Skin Crackers Agro-industry Using Spinner in Selong District, East Lombok Regency}

\author{
Agriananta Fahmi Hidayat*, ${ }^{*}$, Hary Kurniawan ${ }^{1}$, Rucitra Widyasari ${ }^{2}$ \\ ${ }^{1}$ Program Studi Teknik Pertanian, Universitas Mataram, Nusa Tenggara Barat, Indonesia \\ ${ }^{2}$ Program Studi Ilmu dan Teknologi Pangan, Universitas Mataram, Nusa Tenggara Barat, \\ Indonesia \\ *Penulis Korespondesi \\ Email: agriananta.fahmi@unram.ac.id
}

\begin{abstract}
Abstrak. Salah satu agroindustri unggulan di Lombok Timur, Provinsi Nusa Tenggara Barat yaitu kerupuk kulit yang sebagian besar manajerialnya merupakan Usaha Kecil, Mikro, Menengah (UMKM). UMKM tersebut rentan terhadap perubahan ekonomi dan berdampak besar terhadap keuangan industri tersebut. Analisis kelayakan usaha sangat dibutuhkan untuk mempertimbangkan perubahan nilai mata uang (NPV), tingkat suku bunga (IRR), serta melihat perbandingan rasio biaya yang dikeluarkan dengan jumlah manfaat yang akan diperoleh (b/c ratio) serta perhitungan nilai investasi bila usaha ini akan dikembangkan (PP) dan analisis sensitivitas. Analisis dilakukan menggunakan metode eksperimental dan wawancara terhadap pelaku usaha. Metode eksperimental dilakukan dengan melihat perubahan produktivitas dari usaha kerupuk kulit yang mulanya enggan menggunakan mesin peniris, sedangkan perubahan ekonomi dilihat dari wawancara terhadap pelaku usaha terhadap penambahan mesin untuk produksi. Hasil penelitian diperoleh nilai NPV lebih besar dari 0 yaitu Rp. 3.942.875.937. PP terhitung 2 tahun dibawah periode usaha. Rasio B/C lebih dari 1 yaitu 4,34 Hasil analisis diatas menunjukkan bahwa agroindustri kerupuk kulit dengan mesin peniris layak dijalankan. Analisis sensitivitas menunjukkan bahwa dengan inflasi 7,26\% tidak berdampak signifikan terhadap usaha kerupuk kulit.
\end{abstract}

Kata kunci: analisis finansial, kerupuk kulit, mesin peniris

Abstract. One of the superior products from NTB is processed food products from cattle farms in the form of meat and by-products, namely cow leather into crafts and food products (crackers). Hide cracker agroindustry in East Lombok is mostly Small, Micro, Medium Enterprises (MSMEs) which if there is an economic change it will have a major impact on the financial industry. So, we need a business feasibility analysis by considering changes in currency values $(N P V)$, interest rates (IRR), as well as looking at the ratio of the costs incurred to the number of benefits to be obtained ( $b / c$ ratio) as well as calculating the value of the investment if this business will be developed (PP) and sensitivity analysis. It was revealed that NPV was positive $R p$. 3,942,875,937, the payback period for 2 years does not exceed the planned business period, $B / C$ ratio was 4.34, whose value is greater than 1. Thus, the hide cracker agroindustry is therefore possible based on the financial analysis. Sensitivity analysis with inflation $7.26 \%$ did not have any influence.

Keywords: financial analysis, skin crackers, spinner 


\section{Pendahuluan}

Salah satu produk unggulan dari Provinsi Nusa Tenggara Barat (NTB) selain produk hasil pertanian adalah produk pangan olahan hasil dari peternakan sapi baik berupa daging maupun produk sampingan yaitu kulit sapi menjadi kerajinan maupun produk pangan (kerupuk). Walaupun sejak 2003 Pemerintah giat mencanangkan sektor peternakan sebagai produk unggulan, namun dampak secara ekonomi belum dirasakan secara signifikan oleh peternak sapi (Kurniawan et al., 2019). Apabila potensi yang sedemikian besar tersebut dikelola dengan baik dari setiap titik rantai pasok dengan seiring majunya industri seperti saat ini maka akan timbul efek positif lainnya seperti pemicu munculnya industri baru (agen penjualan, jasa pengiriman) sehingga memperbesar nilai tambah (Soekartawi,2001)

Agroindustri dapat diartikan sebagai kegiatan pengolahan lanjut berbasis hasil pertanian yang bertujuan menambah nilai jual hasil pertanian, sehingga dihasilkan diversifikasi produk olahan, memperpanjang umur simpan, serta menyempurnakan hasil pertanian (Nurhayati, 2019). Kerupuk kulit merupakan salah satu hasil pengolahan hasil peternakan dengan nilai penjualan (volume jual atau omzet) hingga 68 miliar dengan jumlah pelaku usaha 75 orang yang tersebar di kota Mataram. Tidak hanya di kota mataram, di Kabupaten Lombok Timur terdapat 11 pelaku usaha dapat menghasilkan nilai penjualan mencapai 1 miliyar dengan minimum hari kerja 175 dan maksimum 335 hari yang jika dirata-ratakan jumlah produksi pertahun 5.104-5.796 Kg.

Pada umumnya, produk pangan tradisional tidak memiliki perhitungan jumlah dan kapasitas produksi tidak tetap pertahunnya. Salah satu faktornya adalah jumlah hari kerja yang tidak sama. Selain kultur masyarakat, jumlah hari kerja juga sangat tergantung pada permintaan pasar serta secara teknis dipengaruhi oleh perbedaan waktu proses produksi. Hal ini mengakibatkan total hari produksi pada industri pengolahan pangan lokal olahan secara optimal mampu dicapai hingga 355 dan paling rendah selama 175 hari dalam satu tahun produksi.

Berdasarkan nilai produksi yang dihasilkan, peluang pengembangan produk kerupuk kulit sangat menjanjikan terutama bila merujuk pada target daerah sebagai salah satu penggerak perekonomian dan menciptakan lapangan pekerjaan sehingga dapat mengurangi angka pengangguran yang secara tidak langsung dapat meningkatkan kesejahteraan masyarakat. Hasanudin (2015) melaporkan bahwa kerupuk kulit sebagai salah satu produk pangan olahan berbasis hasil peternakan di wilayah Lombok Timur masih belum mendapat dukungan Pemerintah.

Dampak secara ekonomi untuk usaha kerupuk kulit dapat diprediksi dengan mempertimbangkan berbagai faktor, utamanya adalah sensitivitas terhadap perubahan nilai mata uang. Hal inilah yang belum diperhitungkan secara matang oleh pelaku usaha, sehingga jika 
terjadi fluktuasi bahan baku dan permintaan yang berpengaruh terhadap pendapatan pelaku usaha akan terlambat untuk mulai menaikkan harga, terutama jika menyangkut keuangan dan kepercayaan konsumen. Untuk menaikkan harga produk secara tiba-tiba tentu bisa merubah pangsa pasar, sehingga seharusnya studi ekonomi harus dibuat secara berkala.

Dukungan yang besar dari Pemerintah maupun sumber daya melimpah jika diperkuat dengan proyeksi ekonomi yang tepat, maka tidak hanya akan menjadi produk unggulan daerah namun juga unggulan Indonesia karena secara umum produk pangan ini tidak asing bagi daerah lain. Keterbaruan penelitian ini adalah bahwa pada permasalahan di Lombok Timur terkait produk kerupuk kulit adalah belum terdapat data ilmiah yang dapat menunjang usaha kerupuk kulit terutama pada aspek kelayakan finansial. Penelitian terhadap analisis kelayakan usaha dengan mempertimbangkan selain sensitivitas perubahan nilai mata uang (NPV), tingkat suku bunga (IRR), serta melihat perbandingan rasio biaya yang dikeluarkan dengan jumlah manfaat yang akan diperoleh (B/C ratio) serta perhitungan nilai investasi bila usaha ini akan dikembangkan (PP).

Analisis usaha yang dilakukan dengan mempertimbangan penggunaan mesin berupa mesin peniris minyak. Sugandi et al. (2018) melaporkan bahwa mesin peniris minyak banyak diaplikasikan oleh pengrajin kerupuk karena dapat membantu mengurangi kandungan minyak usai produk digoreng. Mesin tersebut sudah dikembangkan baik dari kecepatan berputar, diameter lubang peniris minyak, bahan yang digunakan hingga dimensi yang sesuai dengan kebutuhan produksi serta sifat bahan sehingga selain dapat mengurangi minyak dari kerupuk juga mencegah terjadinya ketengikan akibat pengemasan serta penyimpanan yang tidak tepat.

\section{Bahan dan Metode}

Penelitian ini dilakukan dengan menggunakan metode pengamatan secara langsung secara eksperimental dengan menggunakan mesin peniris minyak dengan spesifikasi mesin penggerak motor induksi single phase 0,25HP, $1400 \mathrm{RPM}, 0,18 \mathrm{KW}$. Mesin peniris minyak memiliki diameter ruang peniris $50 \mathrm{~cm}$ dengan ketinggian $40 \mathrm{~cm}$ gambar mesin dapat dilihat pada Gambar 1 dan hubungannya dengan peningkatan produktivitas usaha serta dengan wawancara terhadap pemilik usaha mengenai dampak dari penggunaan alat tersebut. Pembuatan langsung produk kerupuk kulit dilakukan guna mengetahui kebutuhan produksi, seperti bahan baku kerupuk kulit, alat dan mesin, operasional serta tenaga kerja dalam proses produksi. Data-data tersebut kemudian diolah sesuai parameter menggunakan perangkat lunak Microsoft Word 2016 dan Microsoft Excel 2016 sedangkan untuk perangkat keras menggunakan Laptop merk Asus. Mesin peniris yang digunakan adalah mesin dengan prinsip kerja menggunakan gaya sentrifugal. 

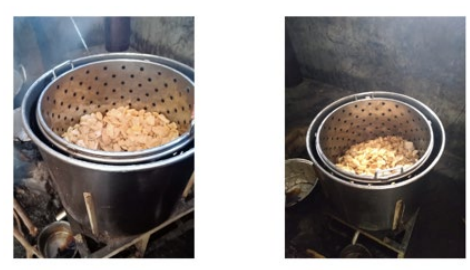

Gambar 1. Mesin Peniris

Analisis kelayakan finansial memiliki beberapa parameter, antara lain analisis Net Present Value (NPV), Incremental Rate of Return (IRR), Net Benefit Cost Ratio (Rasio B/C) dan Pay Back Period (PBP).

\section{Net Present Value (NPV)}

Tujuan parameter NPV adalah untuk mendapatkan gambaran berapa nilai investasi berdasarkan perubahan nilai mata uang. Parameter ini menyatakan perubahan nilai saat ini dari keuntungan dan biaya (Pujawan, 2004). Perumusan NPV dapat dilihat pada Persamaan 1.

$$
N P V=\sum_{1=1}^{n} \frac{(B t-C t)}{(1+i)^{t}}
$$

Dimana:

$\mathrm{Bt}=$ penerimaan pada tahun ke- $\mathrm{t}$

$\mathrm{Ct}=$ biaya pada tahun ke- $\mathrm{t}$

$\mathrm{i}=$ suku bunga yang digunakan

$\mathrm{t}=$ tahun ke- $\mathrm{t}$

$\mathrm{n}=$ umur ekonomi

NPV memiliki parameter kelayakan yaitu, jika nilai yang diperoleh positif memberikan penegertian bahwa kegiatan tersebut dikategorikan layak untuk dijalankan, sebaliknya jika nilai yang diperoleh negatif maka usaha dikategorikan tidak layak, akan tetapi jika nilai sama dengan 0 maka investasi tersebut dalam kondisi yang dikatakan tidak untung ataupun tidak rugi.

\section{Incremental Rate of Return (IRR)}

IRR diartikan sebagai tingkat suku bunga yang maksimum dimana pada tingkat suku bunga tersebut merupakan tingkat kemampuan membalikan biaya yang diinvestasikan (Gittinger, 1986). IRR dihitung melaui Persamaan 2

$$
I R R=i_{1}+\frac{N P V_{1}}{N P V_{1}-N P V_{2}} \times\left(i_{2}-i_{2}\right)
$$

keterangan:

$\mathrm{i}_{1} \quad=$ suku bunga NPV positif

$\mathrm{i}_{2} \quad=$ suku bunga NPV negatif

NPV1 = nilai NPV positif

NPV2 = nilai NPV negatif 
Nilai MARR (Marginal Average Revenue Return) digunakan sebagai acuan untuk meilhat parameter IRR, jika nilai IRR melebihi nilai MARR maka usaha dinyatakan feasible. Adapun rumus untuk menentukkan nilai MARR dapat dilihat pada Persamaan 3. (Kusuma, 2014).

$$
M A A R=(1+i)(1+f)-1
$$

keterangan:

$\mathrm{I}=$ suku bunga investasi

$\mathrm{f}=$ inflasi tertinggi

\section{Benefit Cost Ratio (Rasio B/C)}

Benefit Cost Ratio (Rasio B/C) yang dihitung melalui Persamaan 4 diartikan sebagai rasio antara nilai benefit (manfaat) dan cost (biaya), guna memperoleh komparasi antara jumlah manfaat dan biaya yang diperoleh.

$$
B C R=\frac{\sum_{t}^{n} B_{t} /(1+i)^{t}}{\sum_{t}^{n} C_{t} /(1+i)^{t}}
$$

Keterangan:

$\mathrm{Bt}=$ nilai manfaat pada tahun ke-t

$\mathrm{Ct}=$ nilai biaya pada tahun ke- $\mathrm{t}$

I = nilai suku bunga

$\mathrm{t}=$ tahun ke- $\mathrm{t}$

Apabila nilai Net $\mathrm{B} / \mathrm{C}>1$, maka dapat dikatakan bahwa kegiatan yang dilakukan cukup layak, sedangkan sebaliknya jika Net $\mathrm{B} / \mathrm{C}<1$ dapat dikatakan usaha tidak layak.

\section{Payback Period (PP)}

Payback period adalah parameter untuk menghitung lama waktu investasi yang dikeluarkan rencana usaha bisnis agar dapat kembali (Yulia et al., 2019). Perumusan mencari nilai PP menggunakan Persamaan 5.

$$
P P=\frac{\text { investasi awal }}{\text { penerimaan periode }} \times 1 \text { tahun }
$$

Indikator kelayakan terjadi apabila nilai PP lebih kecil atau sama dengan periode usaha.

\section{Penyusutan}

Metode perhitungan penyusutan peralatan menggunakan metode garis lurus, dimana besarnya beban penyusutan tiap tahun adalah konstan (Murjana, 2020). Perumusan penyusutan metode garis lurus menggunakan Persamaan 6.

$$
D=\frac{A-S}{N}
$$

Keterangan:

$\mathrm{D}=$ beban penyusutan tiap periode

$\mathrm{A}=$ biaya yang dikeluarkan

$\mathrm{S}=$ nilai sisa

$\mathrm{N}=$ nilai umur ekonomis 


\section{Break Even Point (BEP)}

BEP atau titik impas didefinisikan sebagai titik untuk melihat berapa banyak jumlah produksi yang harus dipenuhi untuk dapat menutupi biaya yang telah dikeluarkan, atau dengan kata lain margin yang diterima sama dengan nol. BEP dirumuskan seperti pada Persamaan 7 atau Persamaan 8 (Pujawan, 2004).

Analisis kelayakan finansial bertujuan untuk mendapatkan gambaran berdasarkan hasil penetlian apakah produksi kerupuk kulit dengan menggunakan mesin penirirs layak atau tidak. Terdapat beberapa asumsi dalam analisis yaitu: (1) masa usaha disesuaikan dengan nilai ekonomis mesin yaitu 5 tahun; (2) perhitungan penyusutan menggunakan metode garis lurus; (3) tingkat suku bunga adalah 7\%, mengacu suku bunga kredit UMKM.

$$
\text { BEP Unit }=\frac{F C}{P-V C}
$$

atau

Keterangan:

$$
\text { BEP Rupiah }=\frac{F C}{1-\frac{V C}{P}}
$$

$$
\begin{array}{ll}
\mathrm{FC} & =\text { Biaya Tetap } \\
\mathrm{P} & =\text { Harga jual per unit } \\
\mathrm{VC} & =\text { Biaya variabel per unit }
\end{array}
$$

\section{Hasil dan Pembahasan}

Berdasarkan hasil wawancara dengan pemilik usaha penggunaan mesin peniris berdampak positif. Produk awal sebelum menggunakan mesin peniris terdapat sisa-sisa minyak pada plastik

\begin{tabular}{|c|c|c|c|c|c|c|c|c|}
\hline Nama & Jumlah & Satuan & & Total & $\begin{array}{c}\text { Umur } \\
\text { Ekonomis }\end{array}$ & Nilai Sisa & \multicolumn{2}{|c|}{ Penyusutan } \\
\hline Spinner & 1 & unit & $\mathrm{Rp}$ & 5.000 .000 & 5 & Rp 1.000 .000 & $\mathrm{Rp}$ & 800.000 \\
\hline Ember & 2 & pcs & $\mathrm{Rp}$ & 150.000 & 2 & $\mathrm{Rp}-$ & $\mathrm{Rp}$ & 75.000 \\
\hline Bak & 11 & pes & $\mathrm{Rp}$ & 385.000 & 2 & $\mathrm{Rp}-$ & $\mathrm{Rp}$ & 192.500 \\
\hline Bakul & 4 & pes & $\mathrm{Rp}$ & 340.000 & 2 & $\mathrm{Rp}-$ & $\mathrm{Rp}$ & 170.000 \\
\hline Panci besar & 3 & pcs & $\mathrm{Rp}$ & 615.000 & 3 & $\mathrm{Rp}-$ & $\mathrm{Rp}$ & 205.000 \\
\hline Kompor gas & 3 & unit & $\mathrm{Rp}$ & 1.050 .000 & 3 & $\mathrm{Rp}-$ & $\mathrm{Rp}$ & 350.000 \\
\hline Pisau & 4 & pcs & $\mathrm{Rp}$ & 400.000 & 1 & $\mathrm{Rp}-$ & $\mathrm{Rp}$ & 400.000 \\
\hline Wajan besar & 3 & pcs & $\mathrm{Rp}$ & 2.100 .000 & 2 & $\mathrm{Rp}-$ & $\mathrm{Rp} 1$ & .050 .000 \\
\hline Timbangan besar & 1 & pcs & $\mathrm{Rp}$ & 1.500 .000 & 5 & $\mathrm{Rp}-$ & $\mathrm{Rp}$ & 300.000 \\
\hline Timbangan gantung & 1 & pes & $\mathrm{Rp}$ & 850.000 & 5 & $\mathrm{Rp}-$ & $\mathrm{Rp}$ & 170.000 \\
\hline Timbangan duduk & 1 & pcs & $\mathrm{Rp}$ & 150.000 & 3 & $\mathrm{Rp}-$ & $\mathrm{Rp}$ & 50.000 \\
\hline Parang & 4 & pcs & $\mathrm{Rp}$ & 500.000 & 3 & $\mathrm{Rp}-$ & $\mathrm{Rp}$ & 166.667 \\
\hline Talenan kayu & 3 & pes & $\mathrm{Rp}$ & 1.200 .000 & 3 & $\mathrm{Rp}-$ & $\mathrm{Rp}$ & 400.000 \\
\hline Alat siset & 2 & pcs & $\mathrm{Rp}$ & 200.000 & 2 & $\mathrm{Rp}-$ & $\mathrm{Rp}$ & 100.000 \\
\hline \multicolumn{2}{|c|}{ Jumlah } & & \multicolumn{2}{|c|}{ Rp14.440.000 } & & Rp 1.000 .000 & \multicolumn{2}{|c|}{$\mathrm{Rp} 4.429 .167$} \\
\hline
\end{tabular}
kemasan, akan tetapi setelah menggunakan mesin penisir minyak yang menempel di kemasan tidak banyak. Hal ini menunjukkan bahwa mesin peniris mampu mereduksi jumlah minyak pada produk kerupuk kulit.

Tabel 1. Biaya Alat 
Berdasarkan hasil dilapangan diperoleh data bahwa usaha kerupuk kulit dalam 1 hari usaha tersebut beroperasi 8 jam, mampu mengolah bahan baku sebesar $162 \mathrm{~kg}$ kulit sapi dengan harga per kilogram adalah berkisar Rp. 30.000 sampai Rp. 55.000 berdasarkan lokasi bahan baku yang diperoleh apakah dari lokal atau dari luar. Bahan tersebut mampu menghasilkan $84 \mathrm{~kg}$ kerupuk kulit siap konsumsi dengan harga jual per kg adalah Rp. 95.000, dengan profit keuntungan 44\%.

Usaha agroindustri cenderung memiliki biaya investasi dan biaya operasional. Peralatan dan mesin dalam mendukung usaha agroindustri dapat dikategorikan sebagai biaya investasi (Hidayat et al., 2018). Biaya investasi ditunjukkan Tabel 1. Biaya operasional menyatakan cost yang nilainya dilihat berdasarkan jumlah produk yang diproduksi. Biaya tetap dan biaya varibel merupakan bagian dari biaya operasional. Pada usaha agroindustri kerupuk kulit memiliki biaya tetap yaitu biaya susut mesin dan honor tenaga kerja. Sementara itu, biaya bahan baku, biaya bahan pendukung dikategorikan sebagai biaya variabel. Nilai biaya tetap dan biaya variabel ditunjukkan pada Tabel 2.

Tabel 2. Biaya dan pendapatan usaha agroindustri kerupuk kulit

\begin{tabular}{lrr}
\hline & Biaya & \\
\hline Biaya Peralatan & & Nilai (Rp) \\
Biaya Operasional & & $216,440,000$ \\
Biaya Bahan Baku & $65,910,000$ \\
Total Biaya & $297,334,000$ \\
\hline Total Pendapatan & $1,249,309,167$ \\
\hline
\end{tabular}

\section{Analisis Finansial}

Break even point (BEP)

BEP dihitung berdasarkan jumlah unit dan produk, berdasarkan hasil perhitungan BEP unit adalah $472 \mathrm{~kg}$ dan BEP produk adalah Rp. 44.814.270

Net present value (NPV)

Perhitungan NPV menghasilkan nilai yang positif (lebih besar dari 0) yaitu Rp. 3.942.875.937, nilai tersebut menyatakan bahwa nilai investasi dalam 5 tahun yang akan datang mempunyai manfaat nilai sebesar Rp. 3.942.875.937

Internal rate return (IRR)

Sementara itu, nilai IRR sebesar 90,71\% melebihi nilai MARR sebesar 14,8\%. Hal ini menunjukkan bahwa usaha agroindustri kerupuk kulit dari parameter IRR layak untuk dijalankan.

\section{Benefit cost ratio}

Nilai rasio B/C adalah 4,34, nilai tersebut menunjukkan bahwa pengeluaran Rp. 1 akan memperoleh manfaat sebesar Rp. 4,34. 
Tabel 3. Hasil kriteria analisis kelayakan finansial

\begin{tabular}{lr}
\hline \multicolumn{1}{c}{ Kriteria } & Nilai \\
\hline BEP Unit & Rp 44.875.937 \\
BEP Produk & Rp 3.942.875.937 \\
NPV (Rp) & 90.71 \\
IRR (\%) & 4.34 \\
Rasio B/C & 2 \\
PP (tahun) & \\
\hline
\end{tabular}

\section{Payback period}

Payback period usaha ini diperoleh nilai 2 tahun, hal ini memiliki arti bahwa nilai tersebut lebih kecil dari umur invesatasi yang direncanakan yaitu 5 tahun.

Hasil analisis parameter diatas maka usaha tersebut dapat dikatakan layak. Hasil analisis finansial dapat dilihat pada Tabel 3.

\section{Analisis Sensitivitas}

Analisis sensitivitas memiliki fungsi guna melihat sensitivitas usaha terhadap dinamika yang selama periode investasi. Ketidakpastian dalam usaha merupakan faktor terjadinya perubahan. Faktor ketidakpastian tersebut diantaranya harga bahan yang meningkat dan atau harga produk mengalami penurunan. Analisis sensitivitas menggunakan tiga skenario yang dapat dilihat pada Tabel 4. Pendekatan inflasi dilakukan dalam perhitungan analisis sensitivitas (Yulianti \& Sari, 2008). Nilai inflasi, menggunakan nilai inflasi tertinggi yang terjadi dalam kurun waktu 5 tahun (Januari 2014 - Desember 2018). Nilai inflasi tertinggi terjadi pada bulan bulan Juni dan Juli 2015 yaitu sebesar 7,26\%.

Tabel 4 . Skenario analisis sensitivitas.

\begin{tabular}{|c|c|}
\hline Skenario & Kondisi \\
\hline \multirow{2}{*}{ I } & Kenaikan harga produksi \\
\hline & Nilai pendapatan tetap \\
\hline \multirow{2}{*}{ II } & Harga produksi tetap \\
\hline & Niali pendapatan turun \\
\hline \multirow{2}{*}{ III } & Kenaikan harga produksi \\
\hline & Niali pendapatan turun \\
\hline
\end{tabular}

Tabel 5. Hasil kriteria analisis kelayakan finansial.

\begin{tabular}{lcc}
\hline & \multicolumn{2}{c}{ KRITERIA } \\
\cline { 2 - 3 } & NPV & Rasio B/C \\
\hline Skenario I & Rp 3.169.675.799 & 4,0 \\
Skenario II & Rp 2.934.440.435 & 4,0 \\
Skenario III & Rp 2.863.959.709 & 3,8 \\
\hline
\end{tabular}

Berdasarkan hasil analisis sensitivitas dengan kenaikan nilai produksi sesuai dengan nilai inflasi tertinggi 7,26\%, maka tiga skenario tersebut didapatkan informasi bahwa usaha kerupuk 
kulit tetap layak dijalankan dan dikembangkan jika skenario I, II dan III terjadi. Hasil perhitungan dapat dilihat pada Tabel 5 .

\section{Kesimpulan}

Hasil analisis kelayakan finansial usaha didapatkan nilai NPV lebih besar dari 0 sebesar Rp. 3.942.875.937. PP selama 2 tahun tidak melebihi periode usaha yang direncanakan. Rasio B/C 4.34 yang nilainya lebih besar dari 1. Dari aspek finansial maka usaha agroindustri kerupuk kulit dengan mesin peniris dapat dikatakan layak. Analisis sensitivitas melalui pendekatan inflasi dengan nilai inflasi 7,26\% dan pada skenario I, II dan III tidak berpengaruh terhadap usaha agroindustri kerupuk kulit.

\section{Ucapan Terima Kasih}

Ucapan terima kasih disampaikan peneliti kepada Direktorat Riset dan Pengabdian Masyarakat, Direktorat Jenderal Penguatan Riset dan Pengembangan, Kementerian Riset, Teknologi dan Pendidikan (DRPM DIKTI). DRPM DIKTI memberikan pendanaan program pengabdian 2019 sehingga dapat menghasilkan penelitian ini.

\section{Daftar Pustaka}

Gittinger, J. P. (1986). Analisis Ekonomi Proyek-Proyek Pertanian. Jakarta, Indonesia: UI Press. Hasanudin, I. (2015). Analisis Keanekaragaman Produksi Pangan Lokal Olahan di Kabupaten Lombok Timur (Thesis). Retrieved from http://eprints.unram.ac.id

Hidayat, A. F., Baskara, Z. W., Werdiningsih, W., \& Sulastri, Y. (2018). Analisis Kelayakan Finansial Usaha Agroindustri Abon Ikan di Tanjung Karang, Kota Mataram. Jurnal Ilmiah Rekayasa Pertanian dan Biosistem, 6(1), 69-75. https://doi.org/10.29303/jrpb.v6i1.77

Kurniawan, H., Widyasari, R., \& Hidayat, A. F. (2019). Teknologi Tepat Guna Bagi Kelompok Usaha Kerupuk Kulit Di Desa Lendang Bedurik, Kecamatan Selong, Kabupaten Lombok Timur (Thesis). Retrieved from http://eprints.unram.ac.id/

Kusuma, P. T. W. W., \& Mayasti, N. K. I. (2014). Analisis Kelayakan Finansial Pengembangan Usaha Produksi Komoditas Lokal: Mie Berbasis Jagung. Agritech, 34 (2), 194-202. https://doi.org/10.22146/agritech.9510

Murjana, A (2020, Juni 14). Rumus Penyusutan, Cara Menghitung, Pengertian dan Contoh Soal. Retrieved from http://www.rumusrumus.com

Nurhayati, A. (2019). Analisis Kelayakan Usaha Agroindustri Tape Singkong di Desa Candibinangun Kecamatan Sukorejo Kabupaten Pasuruan. Agroteknika, 2(2), 75-84. https://doi.org/10.32530/agroteknika.v2i2.38

Pujawan, I. N. (2004). Ekonomi Teknik. Surabaya, Indonesia: Guna Widya.

Soekartawi. (2001). Pengantar Agroindustri. Jakarta, Indonesia: PT. Raja Grafindo Persada

Sugandi, W., Kramadibrata, A. M., Fetriyuna, Prabowo, Y. (2018). Analisis Teknik dan Uji Kinerja Mesin Peniris Minyak (Spinner). Jurnal Ilmiah Rekayasa Pertanian dan Biosistem, 6(1), 17 - 26. https://doi.org/10.29303/jrpb.v6i1.65

Yulia, A., Sari, F. P, \& Arisandi, M. (2019). Analisis Kelayakan Pendirian Usaha Pengolahan Tempurung Kelapa di Kecamatan Pengabuan, Kabupaten Tanjung Jabung Barat, Provinsi Jambi. Industria: Jurnal Teknologi dan Manajemen Industri, 8(2), 145-153. https://doi.org/10.21776/ub.industria.2019.008.02.7

Yulianti \& Sari, N. (2008). Kelayakan Usaha Agroindustri Bawang Goreng Palu di Kabupaten Donggala. Agroland, 15(3), 216-222. 